ENTREPRENEURSHIP AND SUSTAINABILITY ISSUES

ISSN 2345-0282 (online) http://jssidoi.org/jesi/

2019 Volume 6 Number 4 (June)

http://doi.org/10.9770/jesi.2019.6.4(18)

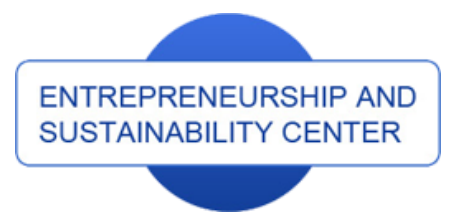

Publisher

http://jssidoi.org/esc/home
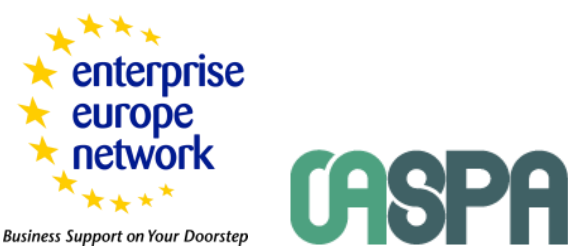

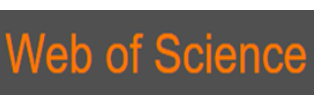

I Clarivate

Analytics

\title{
METHODOLOGICAL BASIS OF ECONOMIC DECISION-MAKING
}

\author{
Natalya Pavlovna Vinogradova, Alexander Nikolaevich Popov \\ ${ }^{1}$ The Ural State University of Physical Culture, Ordzhonikidze Str., 1, Chelyabinsk, 454091, Russia \\ ${ }^{2}$ The State University of Chelyabinsk, Kostanay Branch, Baitursynov Str., 47, Kostanay, 110000, Kazakhstan \\ E-mails: ${ }^{1}$ popov_a_n@inbox.ru $;{ }^{2}$ vinogradova_n_p@mail.ru
}

Received 15 February 2019; accepted 16 April 2019; published 30 June 2019

\begin{abstract}
The article aims to substantiate the methodological basis of economic decision-making as a science of choosing the most efficient ways of management carried out by corporate executives. Cooperation principles and methods in the system of collective entrepreneurship are closely connected to business success in corporate activities. The compliance with important corporate principles is conducive to the development of optimum managerial decisions. Managerial decisions provide a company's competitive advantages in the goods and services markets and normal operation of staff in these businesses. In the paper the author present original methodological approach towards decision making process.
\end{abstract}

Keywords: decision-making; utilitarianism; leadership; corporate management

Reference to this paper should be made as follows: Vinogradova, N.P.; Popov, A.N. 2019. Methodological basis of economic decisionmaking, Entrepreneurship and Sustainability Issues 6(4): 1798-1806. http://doi.org/10.9770/jesi.2019.6.4(18)

JEL Classifications: M1

\section{Introduction}

The article concerns the concept of economizing of decision-making. Structurally, it constitutes a combination of the following theoretical provisions (Vinogradova, Popov, 2014): 1) to formulate step-by-step actions (their motivation basis and systems of reference points); 2) to find out trends for efficient and innovative development of self-organizing entrepreneurial entities; 3) to treat what corporate leaders think about finding out and substantiating straightforward actions as a driving force for achieving business success. 


\section{ENTREPRENEURSHIP AND SUSTAINABILITY ISSUES}

ISSN 2345-0282 (online) http://jssidoi.org/jesi/

2019 Volume 6 Number 4 (June)

http://doi.org/10.9770/jesi.2019.6.4(18)

As the authors understand, a corporation is a joint stock company, an independent subject of law that is established to carry out joint activities and attain specific goals. The key words are "corporate management", "corporate culture" and "corporate organization". They are united by the terms "decision-making" (the efficiency and quality of decisions) and "economization", which means that a corporate body musters and further develops institutional experience and an economic mentality (Vinogradov, Popova, Popov, 2017).

From the angle of economization, every corporate manager should be a businessperson. The article is, therefore, especially focused on entrepreneurial, innovative and culture-building management. "The very same spirit of entrepreneurship that can create new private enterprises is required in corporate management, and not only at the initial stage," writes F.J. Rogers. "No matter how big or old a corporation is; if it intends to adequately react to changes and grow all the time, it should preserve this initial spirit that transforms someone's ideas and dreams into real business" (Rogers, 1997).

Corporate management is not only about the sale of goods produced, but also the development of the new ones (of the better quality). It is this factor that constitutes a decisive resource, providing any entrepreneurial enterprise with prosperity on the market. "That's why this area of business is also exclusive competence of senior management," W. Heuer (1992) writes. The above concerns corporate culture that plays an important role in making efficient managerial decisions of both strategic and tactical nature. The issues related to approaches towards managerial decision making processes are under ongoing scientific discussion (Plenkina et al. 2018; Labanauskis et al. 2018; Tvaronavičienė 2018; Tvaronavičienė et al. 2018; Colapinto et al. 2020).

As a whole, the article lays special emphasis on the development of a managerial decision (MD) as a scientific problem. As practice shows, in the course of time - once economic situations and managerial tasks become more complicated - this problem becomes more urgent, especially in the direction of revealing the methodological basis of economic decision-making.

\section{Methods}

Empiric, organizational, psychodiagnostic, with the use of SWOT and COPS analysis of corporate activities.

\section{Results and discussion}

Problems related to the development of an MD, as the main tool of managerial impact, arose in the mid-1960s, owing to the efforts taken by American scientists J. Marn, R. Sauert, G. Simon, etc. This new area, being at the junction of the theory of organization, modeling, the economics of sociology and psychology, was named managerial economics (Remennikov, 2000).

Later this problem was studied by representatives of other scientific approaches to the development of management (process, system and situational).

Issues related to the assessment of efficiency and quality of decision-making and the development of plans of actions in the conditions of uncertainty and risks have become more important over the past few decades. Moreover, nowadays it is impossible not to take into account the economic mentality of decision makers (DMs) and the role of entrepreneurial companies (corporations) in the process. Entrepreneurial companies have been paying much closer attention to economic decision-making from the angle of corporate activities. This concerns complicated decisions made in the conditions of flexible management of entrepreneurial activities and the psychological aspect of MD development. However, of special importance is the systemic understanding of economic decision-making as a science of choosing the most efficient ways of managerial activities for corporate managers (Figure 1). 
Fig.1. Systematic presentation of economic decision-making as a science of choosing the most efficient methods for managerial activities of corporate managers

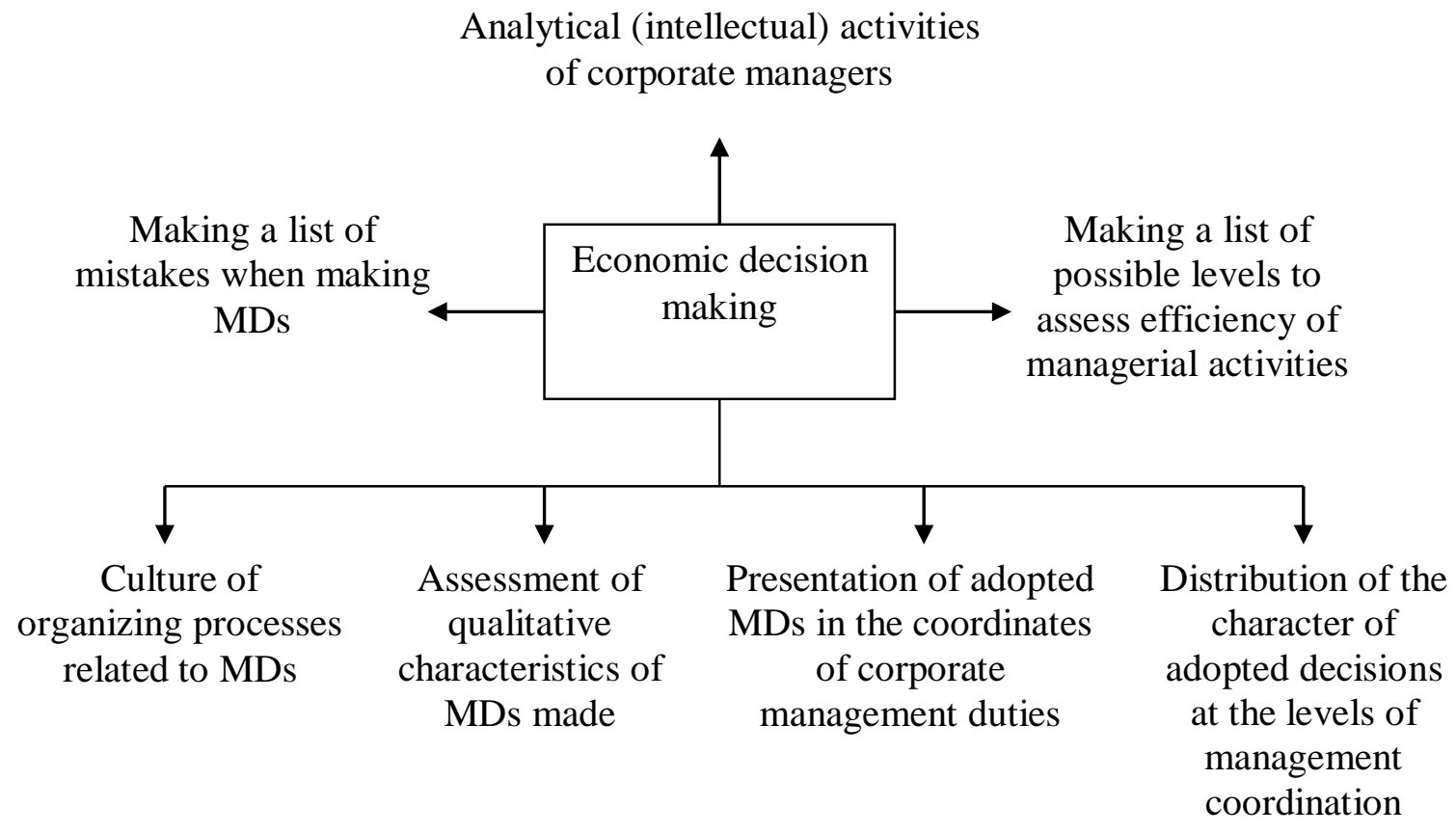

Source: developed by authors

Among the methodological bases of economic decision-making, the authors also mention the model-based presentation of economic decision-making (Figure 2). The following parameters are meant:

1) Rationalization (incentives to make decisions and powers of impact and action);

2) Utilitarianism (to maximize practicability on the basis of effective - corporate - activities);

3) Institutionalization (expectation and attention to consequences of decisions to be made).

Here it is important to focus on the creation of values, organizational culture-building, network management, responsibility and delegation of authority (given trustworthy relations) in the course of operations to achieve business success. 
Fig.2. Model-based presentation of economic decision-making

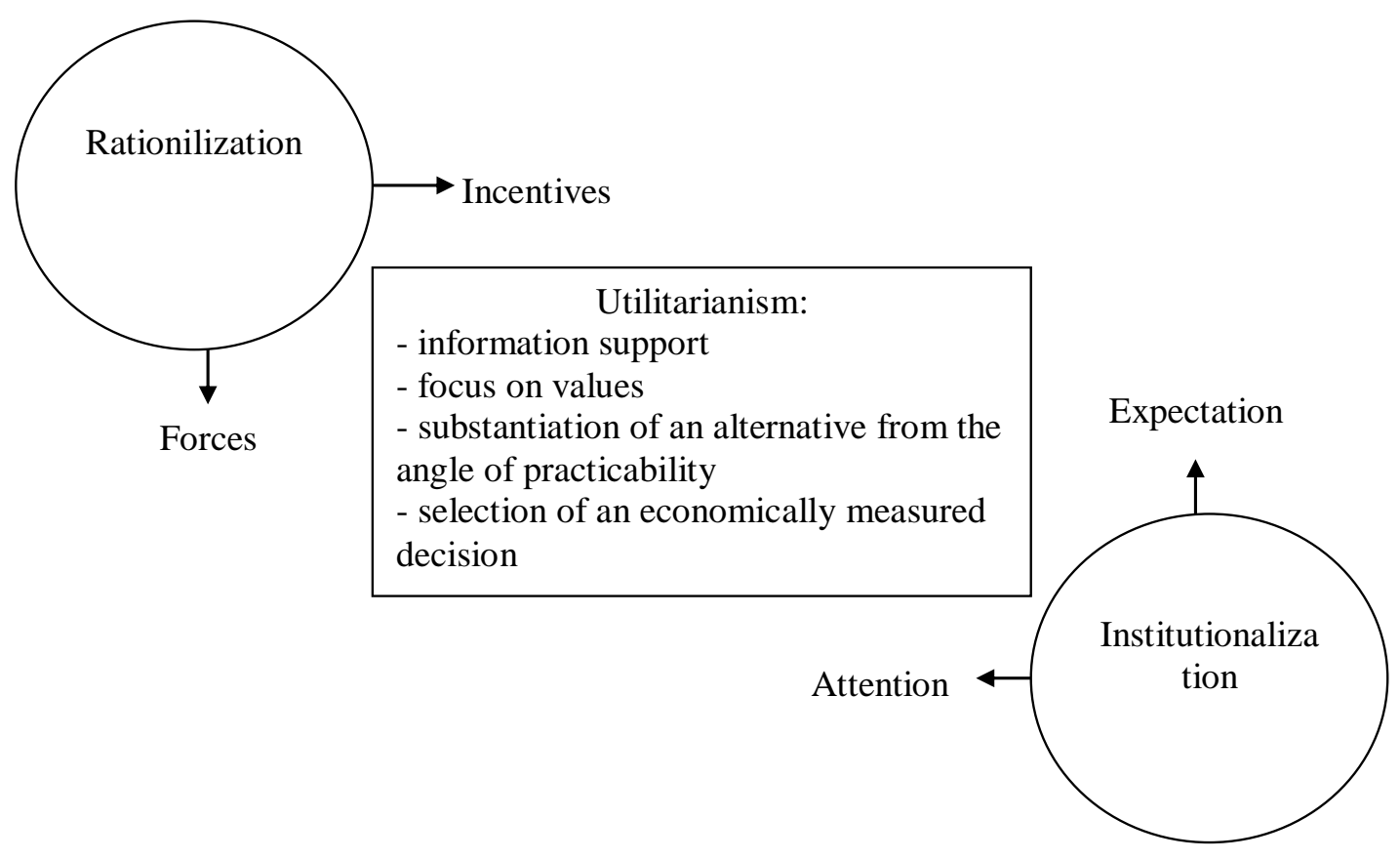

Source: developed by authors

The efficiency of making MDs is one of the most important conditions for the successful development of a corporate organization, its survival in a competitive struggle and successful adaptation to changes in external conditions. At issue is organizational, social, technological, psychological, legal and economic efficiency (the ratio between the cost of an additional product as a result of a specific MD and selling costs). This type of efficiency can be determined if the goal of MD is set in some quantitative indicators relating to the activities carried out by a corporate organization as a whole (or on a specific market or at a certain production stage). Resources, which ensure the efficiency of MD, usually include professionalism of leaders (top managers), their cognitive and organizational talents, as well as finance and incentives in the system under consideration.

In order to be efficient, i.e. to attain some goals set, a decision should meet some requirements. Above all, it should be realistic and include mechanisms of implementation (Dawson, 1996).

MDs are not only a process, but also a condition and result (Table 1). 
Table 1. MD as an integrated concept

\begin{tabular}{|c|c|}
\hline MD & Underlying factor \\
\hline 1. Process & Organizational process, mentality of the organization's leader, its corporate management \\
\hline 2. Condition & Corporate culture as a technological and moral basis for decision-making \\
\hline 3. Result & Efficiency of corporate activities (the MD quality and costs as mental activities and changes in the corporate culture) \\
\hline
\end{tabular}

Source: developed by authors

Decision-making is a "product" manufactured by the leader in the course of management. For this reason, the knowledge of technologies and methods of elaborating MD are an essential element of professional qualification of a corporate leader.

Figure 3 shows the essence of the systematic presentation of MDs adopted in the system of corporate management. The data below can help understand how MDs are taken.

\begin{tabular}{|c|c|c|}
\hline & Making MDs & \\
\hline$\nabla$ & $\frac{1}{7}$ & $\neg$ \\
\hline $\begin{array}{l}\text { MD categories and types: } \\
\text { - programmable and non- } \\
\text { programmable } \\
\text { - organizational and } \\
\text { personal } \\
\text { - operating and strategic } \\
\text { - research and crisis } \\
\text { situational }\end{array}$ & $\begin{array}{l}\quad \text { Primary approaches } \\
\text { towards decision making: } \\
\text { - centralized and } \\
\text { decentralized } \\
\text { - group and individual } \\
\text { - system of involvement } \\
\text { and non-involvement } \\
\text { - democratic and } \\
\text { consultative }\end{array}$ & $\begin{array}{l}\text { Methods and ways of } \\
\quad \text { decision making: } \\
\text { - modeling } \\
\text { - decision tree } \\
\text { - breakeven principle } \\
\text { - decision making amid } \\
\text { risks } \\
\text { - decision making when } \\
\text { unconfident }\end{array}$ \\
\hline
\end{tabular}

Fig.1. Making MD in the coordinates of corporate management

Source: developed by authors

Extensive literature devoted to corporate management shows that the concepts of decision-making and managerial activities are so much interconnected that they are often used as synonyms (Golubkov, 2003). This comes from the following functions of corporate management: strategic planning, innovative management, and organizational culture-building. This is also an analytical (cognitive) activity as a function of the corporation's leader (director) and its agent center.

Executives should analyze, firstly, the business position in the market, secondly, production of goods and services while changing sales activities and, thirdly, delegation of authority in the corporate management system from the viewpoint of market relations as trustworthy. In other words, the creation of the business climate in this system plays a decisive role in promoting successful activities and making efficient decisions on the production and sales 


\section{ENTREPRENEURSHIP AND SUSTAINABILITY ISSUES}

ISSN 2345-0282 (online) http://jssidoi.org/jesi/

2019 Volume 6 Number 4 (June)

http://doi.org/10.9770/jesi.2019.6.4(18)

of goods and services to be manufactured. Not accidentally, specialists pay attention to the following mistakes made by corporate managers:

- checking results instead of impacting a corporate decision;

- not caring about the achievement of business success as important in principle;

- directing all employees in the same manner (they are all different; it is not possible to achieve success without understanding this);

- focusing not on goals, but problems (and on the adoption, in this connection, of efficient MDs).

All of this relates to the methodological basis of economic decision-making of a person authorized to do so as part of corporate management.

It is objectively necessary for such a person to seek a certain external force that should set the order, impose rules of the game, which create a structure of interaction within the corporate management system, and eventually to reduce the degree of uncertainty in interrelations within this system.

This force is institutions (rules and standards) that act as a barrier and prescription of actions capable of forming expectations about achievements when bringing MDs to reality. As such, the authors classify norms of trust and organized culture (and, to a large extent, institutional norms and rules of business ethics, rights of ownership, economic freedom and legislation).

D. North wrote about this the following: "players' mental constructions set by the complexity of the surrounding world, limited information feedback with the results of activities inherited by cultural traditions determine their perception" (North, 1993).

Moreover: "The entrepreneur will assess benefits from entering into new agreements as part of the current institutional structure". As for the latter, at issue are changes in the formal rules that can be the result of legal and constitutional changes that determine the rules (meta-rules), on which the entire system of rules is built.

As M. Mescon and his co-authors fairly said, the core of management is "to impact the organization and change its structure for the purpose of making optimal decisions" (Mescon, Albert, Khedouri, 2004). The authors understand optimal decisions as one of the specific - primary - functions of management (the key factor when performing all other managerial duties). In this regard, speaking about economic decision-making is justified (Popov, Vinogradova, 2017).

\section{Conclusions}

1. The research is based on the methodology of economizing the MD development. In accordance with which, the MD development:

1) Changes a corporation's external condition (financial, socio-economic, scientific-technical);

2) Takes into account time spent and costs incurred to prepare, accept and implement an MD; 


\section{ENTREPRENEURSHIP AND SUSTAINABILITY ISSUES}

ISSN 2345-0282 (online) http://jssidoi.org/jesi/

2019 Volume 6 Number 4 (June)

http://doi.org/10.9770/jesi.2019.6.4(18)

3) Touches upon private and local performance parameters of the entire system of managing corporate activities. When doing so, MD results can produce both positive and negative effect.

2. A number of factors determine the efficiency of an MD. They are the availability of conceptual basis for its development, the application of substantiated methods and models, manageability of an object under management (above all, personnel). Other factors are competency, the level of responsibility and experience of a person who makes an MD, and the level of collegial decision-making.

Necessary terms for right MDs in the area of corporate activities should be determined in the course of research. First and foremost, it is necessary to define a list of mistakes made when making MDs and possible grades for the efficiency of managerial activities. Especially it is important when at issue are non-standard, creative decisions that are inevitable when competition toughens in the goods and services market. These terms relate to the following: 1) constant efforts taken by persons who make MDs to increase qualification; 2) the right way of setting goals (at the personal level of corporate management) and the ability to achieve them; 3) training of independence as a part of self-management; 4) reasonableness of thinking especially when managers have to make urgent MDs that substantially determine business success of the entire corporation.

3. The MD general scheme includes the following elements: goal, means, time, probability (if means and time are available) of resolving a problem (eliminating it), the development of a decision (given analysis of managerial alternatives), control over execution (as an important element of successful management of corporate activities), assessment of a virtually executed MD and the exploration of new possibilities and arising situations. When making an MD, it is also important to answer the question about accounting (what, why, when and how much all these costs, especially when information and the degree of reliability are concerned).

4. One of the methods applied in practice in most cases to assess the efficiency of MDs is the one of profit and cost. Meanwhile, profit is understood as a certain aggregate of criteria that characterize a specific decision. They are both objective and subjective estimates, i.e. payment flows, breakeven period, profitability, and image (Hilkevics, Semakina, 2019)

5. To this way of the conclusion, the authors dedicate the topic of conducting advanced training courses for executives named "Economic decision-making". The topics covered are as follows:

- Specific features of decision-making at a corporate organization (The concept of corporate organization. Management of a corporation. Analysis of the full cycle of managerial activities. Preparation, adoption and execution of a managerial decision. Decision maker. The process of decision-making. The object of a managerial decision, its optimality);

- Optimal mechanisms of making MDs (Theoretical and methodological approaches towards the development of optimal mechanisms to make MDs. Project management. The role and the place of anti-crisis management in the system of corporate management. Requirements of the complex approach to management of corporate activities in the conditions of uncertainty and risks. Corporate culture as a mechanism for making optimal decisions);

- Information support of the process of making an optimal decision (Assessment of required information, its classification. The formation of a research database for the preparation and the adoption of an optimal decision. Catalogues (guides) of analytical information. The place of management accounting in the information system); 


\section{ENTREPRENEURSHIP AND SUSTAINABILITY ISSUES}

ISSN 2345-0282 (online) http://jssidoi.org/jesi/

2019 Volume 6 Number 4 (June)

http://doi.org/10.9770/jesi.2019.6.4(18)

- Decision-making in structured situations (Methods of solving multi-criteria tasks. The search for an optimal decision. The analytical solution of the task related to linear optimization (the simplex method). The automated solution of the task related to linear optimization (Excel). Methods of solving JA tasks. The principle of the maximax and minimax regret. The selection procedure in structured tasks).

\section{References}

Colapinto, C.; Jayaraman, R.; \& La Torre, D. 2020. Goal programming models for managerial strategic decision making, Studies in Systems, Decision and Control, 177, 487-507 https://doi.org/10.1007/978-3-319-99918-0_16

Dawson, R. 1996. The Confident Decision Maker: How to Make the Right Business and Personal Decisions. Translated from English. Moscow: UNITY, 255.

Golubkov, V. N. 2003. Managerial decisions. Management in Russia and Abroad, 1.

Heuer, W. 1992. How to do business in Europe. Moscow: Progress, 253.

Hilkevics, S.; Semakina, V. 2019. The classification and comparison of business ratios analysis methods, Insights into Regional Development 1(1): 48-57. https://doi.org/10.9770/ird.2019.1.1(4)

Labanauskis, R.; Kasparavičiūtè, A.; Davidavičienè, V.; Deltuvienė D. 2018. Towards quality assurance of the study process using the multi-criteria decision-making method, Entrepreneurship and Sustainability Issues 6(2): 799-819. http://doi.org/10.9770/jesi.2018.6.2(22)

Mescon, M.; Albert, M.; Khedouri, F. 2004. Basis of Management. Translated from English. Moscow: Delo, 799.

North, D. C. 1993. Institutions, Ideology and Efficiency of the Economy. From planning to market: the future of post-socialistic republics. Moscow, 307.

Plenkina V.; Andronova I.; Deberdieva E.; Lenkova O.; Osinovskaya, I. 2018. Specifics of strategic managerial decisions-making in Russian oil companies, Entrepreneurship and Sustainability Issues 5(4): 858-874. http://doi.org/10.9770/jesi.2018.5.4(11)

Popov, A. N.; Vinogradova, N. P. 2017. Economic decision-making. Moscow: Russian Academy of Natural History, 210.

Remennikov, V. V. 2000. Development of a Managerial Decision. Moscow: UNITY-DANA, 140.

Rogers, F. J. 1997. The Success Path. How IBM Works. Saint Petersburg: Azbuka-berra, 256.

Tvaronavičienè, M. 2018. Leadership fostering via teaching business case studies: opportunities and limitation. Proceedings of the 2nd International Conference on Social, Economic and Academic Leadership (ICSEAL 2018) Advances in Social Science, Education and Humanities Research ISSN 2352-5398 ISBN 978-94-6252-592-4 Publication date 2018/10/30 doi:10.2991/icseal-18.2018.38, Atlantis Press, p.272-276

Tvaronavičienė, M.; Mentel G.; Chyrva, H. 2018. Leadership in energy security: behavioral patterns and long-term energy intensity. In: Strielkowski W., Chigisheva O. (eds) Leadership for the Future Sustainable Development of Business and Education. Springer Proceedings in Business and Economics. Springer, Cham https://doi.org/10.1007/978-3-319-74216-8_59

https://link.springer.com/chapter/10.1007\%2F978-3-319-74216-8_59\#citeas

Vinogradov, N. P.; Popova, A. A.; Popov, A. N. 2017. Economics of Business Success. Moscow: Russian Academy of Natural History, 210.

Vinogradova, N. P.; Popov, A. N. 2014. Management Economics. Institutional System. Tools to make managerial decisions. Kostanai: Kostanai branch of the Chelyabinsk State University, 2000. 


\section{ENTREPRENEURSHIP AND SUSTAINABILITY ISSUES}

ISSN 2345-0282 (online) http://jssidoi.org/jesi/

2019 Volume 6 Number 4 (June)

http://doi.org/10.9770/jesi.2019.6.4(18)

Natalya Pavlovna VINOGRADOVA

ORCID ID: 0000-0003-2247-5421

Alexander Nikolaevich POPOV

ORCID ID: 0000-0001-6553-5602

Copyright (C) 2019 by author(s) and VsI Entrepreneurship and Sustainability Center

This work is licensed under the Creative Commons Attribution International License (CC BY).

http://creativecommons.org/licenses/by/4.0/

c) (†) Open Access 